\title{
An Overview of Direct Somatic Reprogramming: The Ins and Outs of iPSCs
}

\author{
Siddharth Menon ${ }^{1}$, Siny Shailendra ${ }^{1}$, Andrea Renda ${ }^{2}$, Michael Longaker ${ }^{1,3, *}$ \\ and Natalina Quarto 1,2,*
}

Received: 15 December 2015; Accepted: 13 January 2016; Published: 21 January 2016

Academic Editor: Wenbin Deng

1 Hagey Laboratory for Pediatric Regenerative Medicine, Department of Surgery, School of Medicine, Stanford University, 257 Campus Drive, Stanford, CA 94305, USA; smenon8@stanford.edu (S.M.); sinys@stanford.edu (S.S.)

2 Dipartimento di Scienze Biomediche Avanzate, Universita' degli Studi di Napoli Federico II, Napoli 80131, Italy; renda@unina.it

3 Institute for Stem Cell Biology and Regenerative Medicine, School of Medicine, Stanford University, Stanford, CA 94305, USA

* Correspondence: longaker@stanford.edu (M.L.); quarto@unina.it (N.Q.); Tel.: +1-650-736-1707 (M.L.); +1-650-736-1704 (N.Q.); Fax: +1-650-736-1705 (M.L. \& N.Q.)

\begin{abstract}
Stem cells are classified into embryonic stem cells and adult stem cells. An evolving alternative to conventional stem cell therapies is induced pluripotent stem cells (iPSCs), which have a multi-lineage potential comparable to conventionally acquired embryonic stem cells with the additional benefits of being less immunoreactive and avoiding many of the ethical concerns raised with the use of embryonic material. The ability to generate iPSCs from somatic cells provides tremendous promise for regenerative medicine. The breakthrough of iPSCs has raised the possibility that patient-specific iPSCs can provide autologous cells for cell therapy without the concern for immune rejection. iPSCs are also relevant tools for modeling human diseases and drugs screening. However, there are still several hurdles to overcome before iPSCs can be used for translational purposes. Here, we review the recent advances in somatic reprogramming and the challenges that must be overcome to move this strategy closer to clinical application.
\end{abstract}

Keywords: embryonic stem cells; adult stem; somatic reprogramming; induced pluripotent stem cells (iPSCs)

\section{Introduction}

Stem cells are a subset of cells in our body with the remarkable ability to self-renew and differentiate along different cell-lineages [1]. They can be classified into two main categories based on their self-renewing capacity and plasticity, namely "embryonic stem cells" and "non-embryonic" adult/somatic stem cells. Self-renewal refers to the ability to undergo multiple divisions while maintaining an undifferentiated state, while plasticity refers to the ability of a cell to differentiate down multiple different cell lineages. Plasticity can also be referred to as the potency of a cell.

Embryonic Stem Cells (ESCs) have the unique potential to endlessly divide while maintaining an undifferentiated state (self-renewing) but also the capacity to differentiate into all germ layers as well as extra-embryonic tissues or placental cells, being termed as totipotent. Days after fertilization, these totipotent cells mature and form more specialized cells called pluripotent cells (Figure 1). Pluripotent stem cells maintain the ability to self-renew and differentiate into all three germ layers and down many lineages. These cells, through complex mechanisms are responsible for tissue growth, repair and maintenance. The so-called mouse ESCs (mESCs) are isolated at day E3.5 from the inner cell mass of 
blastocyst [2] whereas human ESCs (hESCs) are isolated from late blastocyst and correspond to the epiblast stem cells of the mouse [3]. Cell lines derived from mouse epiblast share defining features with hESCs [4]. These in vitro derived stem cells are pluripotent and due to their highly regenerative capacity, hESCs are a strong candidate for cell-based therapies, drug studies and disease modeling. However, advances in embryonic stem cell technologies are limited by the controversial source and methods of isolation.

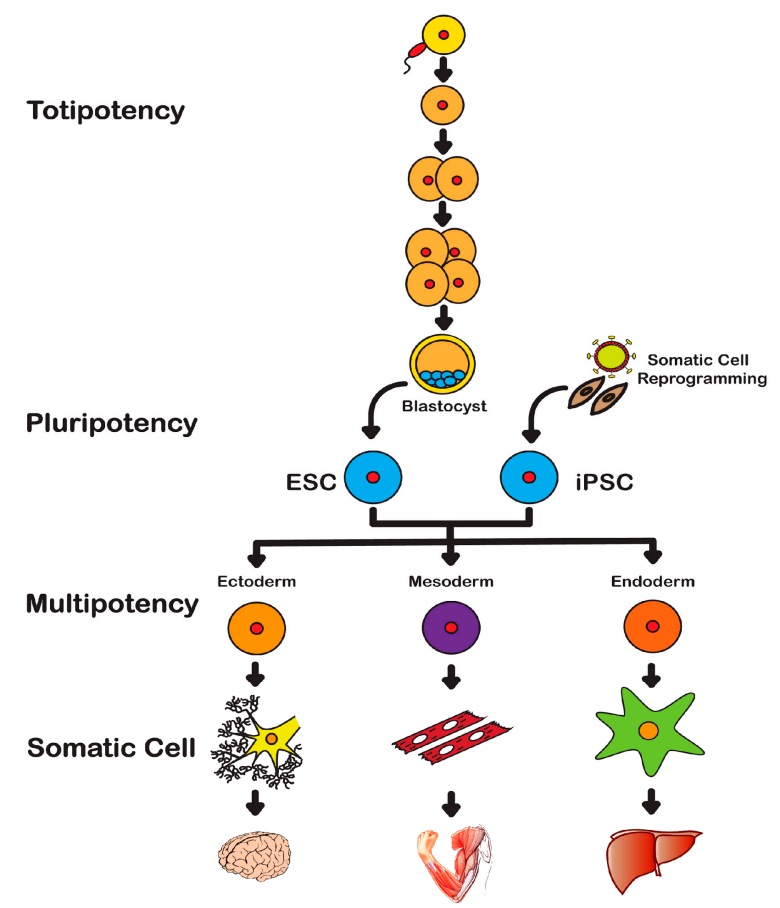

Figure 1. Totipotency: After fertilization, Embryonic Stem Cells (ESCs) maintain the ability to form all three germ layers as well as extra-embryonic tissues or placental cells and are termed as totipotent. Pluripotency: These more specialized cells of the blastocyst stage maintain the ability to self-renew and differentiate into the three germ layers and down many lineages but do not form extra-embryonic tissues or placental cells. Reprogrammed somatic cells, iPSCs, also demonstrate the ability to self-renew and differentiate into all three germ layers in vivo and in vitro. Thus, iPSCs are also considered to be pluripotent stem cells. Multipotency: Adult or somatic stem cells are undifferentiated cells found in postnatal tissues. These specialized cells are considered to be multipotent; with very limited ability to self-renew and are committed to lineage specific differentiation.

Non-embryonic adult/somatic cells are undifferentiated cells found in postnatal tissues. They are more specialized cells and are multipotent, in that they have very limited ability to self-renew, vary in their degree of plasticity (depending on the tissue origin) and are often committed to lineage specific differentiation. These more "mature" cells are referred to as adult or somatic stem cells due to their restricted ability to differentiate. Adult stem cells can be isolated from a variety of sources and are often named after their tissue of origin as follows: Bone Marrow Stem Cells (BMSCs), Adipose-derived Stem Cells (ASCs), Hematopoietic Stem Cells (HSCs) [5-7].

The more recent discovery of induced Pluripotent Stem Cells (iPSCs) may circumvent the several ethical issues and moral conflicts associated with the use of hESCs in clinical applications [8]. Several reports have indicated that iPSCs share features with hESCs both in vitro and in vivo, such as the ability to self-renew and differentiate into many cell types. Indeed, the potential use of iPSCs in regenerative medicine is reassuring for the ethical concerns associated with hESCs and provide potentially an unlimited source of cells for many therapeutic and discovery based applications. 
In this review, after a brief introduction on the history and discovery of ESCs, we will mainly focus on the current derivation procedures, applications and future perspectives of iPSCs; their limitations will be discussed as well.

\section{History of Stem Cells}

\subsection{Embryonic Stem Cells}

Mouse ESCs were the first pluripotent cell type isolated from early embryos. In 1981, Evans and Kaufman [1] and Gail R. Martin [2], independently, described the successful establishment of mESC cultures derived from mouse blastocysts. Since these initial reports of mESCs, derivation of ESC lines has been attempted in several non-rodent species with little success [9]. In 1998, Thomson and colleagues derived hESCs from blastocyst of human embryos produced by in vitro fertilization (IVF) for clinical purpose [3] thus, establishing the first cultured human embryonic stem cells line. Thomson proposed three criteria that defined the primate ESCs: (i) derivation from the pre-implantation or peri-implantation embryo; (ii) prolonged undifferentiated proliferation and iii. STABLE developmental potential to form derivatives of all three embryonic germ layers even after prolonged culture [3]. These valuable properties make hESCs an ideal tool for regenerative medicine, cell therapy and drug discovery. However, their controversial derivation from the cleavage stage of human embryonic tissue has proven to be a significant obstacle in the advancement of embryonic stem cell technologies.

\subsection{Induced Pluripotent Stem Cells}

Pluripotency can also be re-instated in cells of later developmental stages through specific techniques. In 1958, Gurdon et al. [10] using the technique of nuclear transplantation, originally described by Briggs and King [11], showed that the nuclei of intestinal epithelial cells from feeding tadpoles, after transplantation into enucleated eggs, could develop into normal and healthy tadpoles, thus demonstrating successful nuclear reprogramming. This first somatic cell nuclear transfer (SCNT) suggested the presence in ESCs of key-factors inducing and/or maintaining pluripotency. This discovery laid the groundwork for future breakthroughs and achievements in cellular reprogramming.

In 2006, Yamanaka and Takahashi [8] demonstrated the ability to induce a pluripotent state in somatic cells through retroviral-mediated ectopic expression of four genes: Octamer-Binding Transcription Factor 4 (Oct4), SRY (Sex Determining Region Y)-box 2 (Sox2), Kruppel-Like Factor 4 (Klf4) and Avian Myelocytomatosis Viral Oncogene Homolog $(c-M y c)$. These four genes are known also as the "Yamanaka Factors" or OSKM factors. The generation of iPSCs with OSKM has been described as "direct" reprogramming in contrast to reprogramming via nuclear transfer. In addition to Nobel Prize recognition, the discovery of iPSCs has also encouraged scientists to look beyond hESCs for regenerative medicine purposes. These artificially derived pluripotent cells exhibit molecular and functional characteristic similar to those of the embryonic epiblast, and unlike hESCs, iPSCs are not controversial in their source. Moreover, they can potentially provide unlimited autologous cells for cell-based therapies, modeling human diseases, identifying new therapeutic targets and testing new therapies. We will discuss below current reprogramming methods and strategies.

\section{Reprogramming Techniques}

A variety of somatic cell types included fibroblasts, blood, keratinocytes, liver and gastrointestinal cells, as well cancer cells, can be used to derive iPSCs [8,12-22]. As previously mentioned, the initial proof-of-concept studies on generation of mESC-like cells were performed using retroviral transduction of mouse fibroblasts with four specific transcription factors [8]. Currently, several methods exist for generating iPSC lines, but those best suited for studying human diseases and developing therapies must be of satisfactory efficiency and fulfill needs such as generation of iPSCs from samples that may be of limited abundance, ability of reprogramming from different somatic cells, and footprint-free. To 
date, several reprogramming techniques meet these criteria and are readily employed to derive iPSCs (Figure 2).

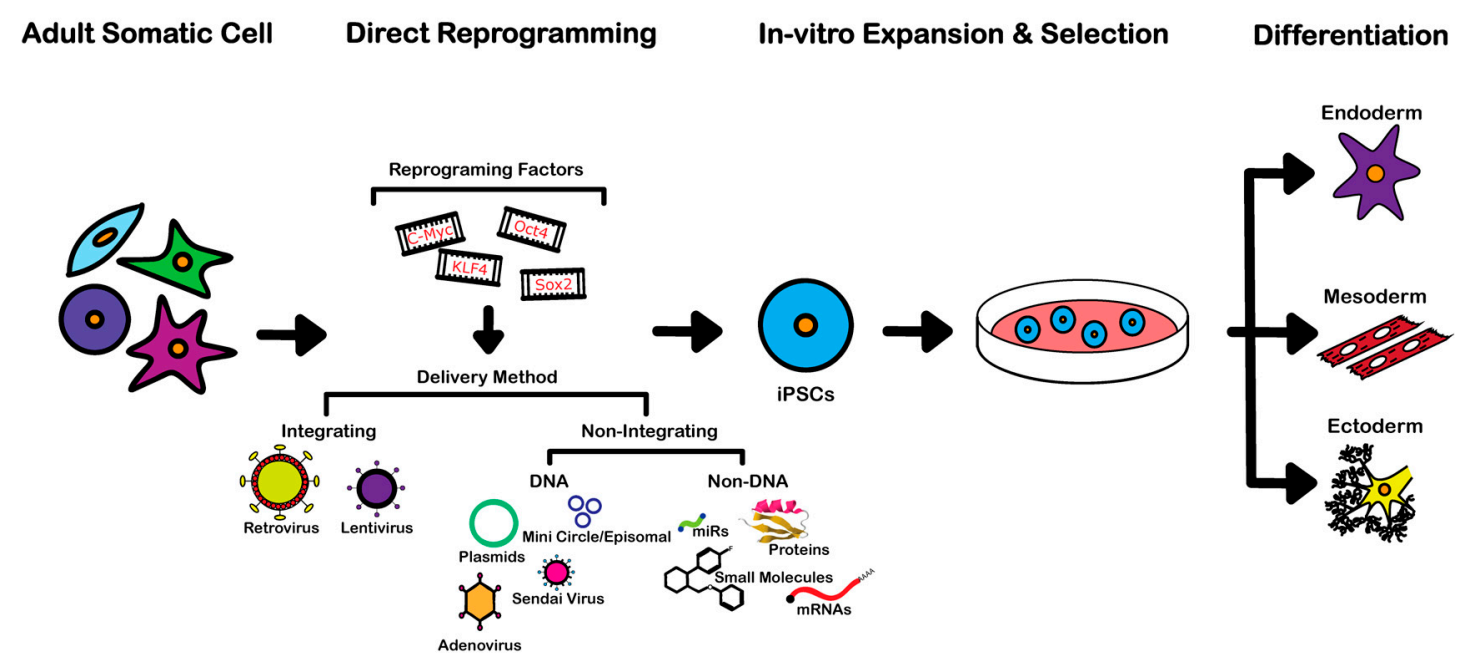

Figure 2. The direct reprogramming of somatic cells to induced pluripotent stem cells (iPSCs) can be achieved through the ectopic expression of specific transcription factors: Oct-4, C-Myc, Sox-2 and $K l f-4$, the "Yamanaka or OSKM Factors". Delivery of these factors can be accomplished through a variety of methods. Initial methods developed integrating retroviral or lentiviral vectors. More recent strategies utilized non-integrating methods, further categorized by the use of DNA such as plasmids, mini circles/episomal, adenovirus, Sendai virus, and non-DNA based procedures such as, mRNAs, microRNAs (miRs), small molecules and bioactive proteins. Once reprogrammed to a pluripotent state, iPSCs can be expanded in vitro and subsequently differentiated to ectoderm, mesoderm and endoderm linages for use in cell therapy, disease modeling and drug discovery.

\subsection{Integrating Procedures}

The first generation of iPSCs was achieved by retroviral transduction technique of OSKM factors into mouse fibroblasts [8]. This method of direct reprogramming of somatic cells to iPSCs utilizes a retroviral-mediated ectopic expression of OSKM identified by Yamanaka and Takahashi through rigorous screening of 24 factors associated with pluripotency. Retroviral transduction to derive iPSCs has been successfully used for several cell types, such as mouse and human fibroblasts, neural stem cells, keratinocytes, adipose cells, liver cells and blood cells. The reprogramming efficiency obtained using human cells is between $0.01 \%-0.02 \%$ [13]. An alternative approach to transduce OSKM factors to derive iPSCs is the use of a lentiviral system which yields a higher efficiency $(0.1 \%-2 \%)$ than retroviral transduction [23]. Although the discovery of Yamanaka factors using retroviral and/or lentiviral systems provides an alternate way to obtain embryonic-like stem cells in limitless quantity, it does have significant drawbacks. The disadvantage of viral integration into the host genome as well as the pro-cancerous role of c-Myc in malignant transformation limit the translational application of iPSCs lines derived in this manner [23-25]. Subsequently, from a clinical perspective, direct reprogramming through retroviral and lentiviral transduction of OSKM factors is not yet translational and various other reprogramming methods have gained popularity.

\subsection{Non-Integrating DNA-Based Procedures}

As previously stated, a major shortcoming of the initial reprogramming strategies is the integration of viral vectors used to transduce the reprogramming factors into host chromosomes. Integration can cause insertional mutagenesis, interference with gene transcription, genome instability and induce malignant transformation [26]. For instance, studies in mice demonstrated iPSC-derived chimeras frequently develop tumors resulting from reactivation of the oncogene c-Myc $[27,28]$. 
Although direct reprogramming has been achieved without c-Myc, it has been shown that the three remaining integrated reprogramming factors could also induce tumors [26,29]. Studies report that retroviral infection leads to an average 10-20 retroviral integration sites in human iPSCs lines [13,30]. Therefore, in order to employ iPSCs for human therapy, their reprogramming should be done using non-integrating strategies. In light of translational goals, several non-integrating virus-mediated iPSCs reprogramming methods have been currently developed.

The development of new techniques such as the transgene excision method, circumvent the potential risks caused by the integration of viral vectors. Recently, several studies have reported alternatives to retroviral integration methods [23,25,31]. One example is a doxycycline (DOX)-inducible lentiviral vector, harboring OSKM factors that can be excised with Cre-recombinase allowing for a differential expression of these reprograming factors, in addition to transfecting both dividing and non-dividing cells, increasing reprogramming efficiency. The first attempt to derive iPSCs without transgene integration used lentiviral vectors containing LoxP sites introduced into the $5^{\prime}$ and $3^{\prime}$ LTR. These LoxP sites provide means of nearly excising all transgene through Cre-mediated recombination [32]. Cre-mediated recombination can be achieved either using picornaviral 2A plasmids or adenoviral Cre. Upon Cre recombination, most of the transgene is excised but a potential risk of insertional mutations from residual vector sequences may not be ruled out. Thus, from a clinical perspective, even minimal residual vector sequences would be a cause for concern when these iPSCs are differentiated and subsequently transplanted into a patient.

The delivery of polycistronic reprogramming OSKM factors expression cassettes with PiggyBack (PB) transposon into somatic cells is another non-integrating method of the simplest and most robust reprogramming approaches representing a low risk reprogramming procedure [33]. This technique utilizes a mobile genetic element that efficiently transposes between vectors and chromosomes with no integration. The PB transposase recognizes specific inverted terminal repeat sequences (ITR) located on either ends of transposon and efficiently integrates them to TTAA sequence chromosomal sites. Woltjen et al. [34] demonstrated successful transposon-based reprogramming of fibroblasts to iPSCs in murine cells with clean excision of vector sequence. Kaji et al. [35], combining a non-viral transfection of a single polycistronic expression vector, harboring the coding sequences of OSKM, with a piggyback transposon procedure succeeded in establishing reprogrammed human cell lines from embryonic fibroblasts. The derived iPSCs expressed robust levels of pluripotency markers and were generated with an efficiency of $0.02 \%-0.05 \%$. Although, there have been reports of successful human iPSCs derived using PB transposons, it must be further demonstrated that the transposons are fully removed prior to employing this procedure for translational purposes. However, some studies suggest that the removal of a large number of transposon copies is difficult to achieve [23,36].

Replication-defective adenoviral vectors expressing OSKM factors have proven useful for derivation of iPSCs because they do not integrate into chromosomal DNA [37,38]. Although they are non-integrating, gene expression can last for days, thus providing sufficient time to reprogram somatic cells to pluripotency. Adenoviral vectors have been largely used to generate iPSCs from liver cells and fibroblasts without viral integration [31,39]. These vectors have lower transduction efficiency in comparison to their retroviral counterparts [31]. While the non-integrating aspect of the adenoviral method is appealing, to be of significant use in translational medicine, optimization of efficiency is necessary.

Non-viral minicircle DNA vectors containing Lin28, GFP (Green Fluorescent Protein), Nanog, Sox2, and Oct4 transcripts have been described as a procedure to derive human iPSCs from human adipose stromal cells with an efficiency of $0.005 \%$ [40]. This method, although non-integrating, lacks sufficient validation to implement in translational studies.

Episomal plasmids provide another method for integration-free reprogramming of somatic cells into iPSCs [41,42]. This procedure has also been used to derive iPSCs from cord blood and peripheral blood cells [43]. This technique yields a very low efficiency, but several modifications by different groups provide promising results for future use [41,42,44]. 


\subsection{Non-Integrating Non-DNA-Based Procedures}

The single-stranded RNA Sendai virus (SV) is also an attractive option for iPSCs derivation, as genomic material does not enter the nucleus of the host cell, does not integrate into the host genome and can be easily removed by antibody-mediated negative selection [45]. Work by Fusaki et al. [45] reported the effective induction of human iPSCs from fibroblasts using Sendai virus as a safe alternative to integrating retroviruses. Sendai virus is potentially a strong candidate for translational research as the efficiency of iPCSs derivation obtained using this procedure is approximately $0.1 \%$, comparable to the lentivirus while remaining non-integrating. Although they are difficult to work with as compared to the lentivirus, commercially available Sendai viral extracts make this a promising alternative procedure.

Another way to avoid the introduction of genetic integrating material into donor cells for their reprogramming to iPSCs is mRNA transfection [46]. RNA-induced pluripotent stem cells (RiPSCs) procedures offer a safe and effective method to generate iPSCs with "null footprint". Additionally, this method of somatic cell reprogramming using synthetic mRNA provides a reduced immunogenic response. Warren et al. [47] demonstrated that repeated administration of synthetic modified messenger RNAs encoding for the OSKM factors, and designed to bypass innate antiviral responses, can reprogram several differentiated human cells to pluripotency with conversion efficiencies and kinetics substantially superior to established viral protocols. Using these methods, Warren et al. [47] derived iPSCs from human keratinocytes, BJ human neonatal fibroblasts, MRC-5 human fetal lung fibroblasts, and cystic fibrosis patient fibroblasts. Although this procedure can reprogram cells at an efficiency of more than $2 \%$, it suffers from major drawbacks: it is time consuming and labor intensive.

The sole expression of specific microRNAs (miRs) clusters also represents a suitable non-integrating, non-DNA-based method to reprogram both mouse and human somatic cells into iPSCs. Miyoshi et al. [48], derived iPSCs by transfecting with a combination of mature miRs clusters, specifically, mir-200c, mir-302s and mir-369s family miRs. These reprogramming miRs were identified upon a large analysis of miRs expression in mouse ESCs, mouse iPSCs, and adult mouse adipose stromal cells. Using this approach several mouse and human iPSCs lines have been derived [49]. Because this reprogramming method does not require vector-based gene transfer, it holds significant potential for regenerative medicine.

Purified OSKM proteins represent another appealing "non-DNA" reprogramming method. Bioactive OSKM proteins at first glance seem as if they are the perfect choice for reprogramming without integrating into host genome [50]. Kim et al. [51] demonstrated generation of stable iPSCs from human fibroblasts by direct delivery of four reprogramming protein factors (OSKM) yielding an efficiency of $0.001 \%$. The human iPSC lines produced with these recombinant proteins (p-iPSCs) were successfully maintained for more than 35 passages and differentiated into derivatives of all three embryonic germ layers both in vitro and in vivo [51]. A major challenge of this procedure is the intracellular delivery of OSKM proteins due to their limited ability to cross the cellular membrane [52]. This can be overcome by fusing them to a short basic segment, namely Cell Penetrating Peptide (CPP), containing a high proportion of basic amino acids (e.g., arginine and lysine) [53,54]. Several studies have reported that CPP-anchored reprogramming OSKM proteins, when delivered into somatic cells, can directly reprogram them successfully without genetic manipulation and/or chemical treatments [50,51]. However, despite successful induction of pluripotency, bioactive reprogramming proteins are difficult to synthesize in large quantities, and efficiency varies between $0.001 \%-4 \%$.

Cellular reprogramming using small molecules may also represent an attractive and convenient alternative to transcription factor-mediated lineage reprogramming. This procedure offers many advantages such as temporally and spatially controllable, reversible, tunable, cell permeability and cost effectiveness. Small molecules used to generate iPSCs are comprised of epigenetic modifiers, WNT signal modulators, cell senescence attenuators, metabolism modulators, and regulators of cell apoptosis/senescence pathways. Small molecules inducing iPSCs can be classified into three types: (1) small molecules that improve reprogramming efficiency [55]; (2) compounds replacing 
one or more reprogramming factors [56-58]; and (3) compound cocktails alone that are sufficient to induce iPSCs $[59,60]$. Small molecule methods have been successfully applied to reprogram mouse fibroblasts directly into functional neurons using only a combination of small molecules $[59,60]$. Induced neural progenitor cells (iNPCs) have also been generated using a chemical cocktail comprised of an inhibitor of GSK-3 kinases and TGF- $\beta$ pathways under physiologically hypoxic conditions [61]. Although several studies have demonstrated that small-molecule-direct reprogramming can completely replace the ectopic OSKM factors in reprogramming into neural lineages, many other studies have combined ectopic transcriptional factors with small molecules to derive neuronal lineages from somatic cells [61-63]. Indeed, small molecule-induced iPSC have dramatically changed iPSC research as highlighted by several studies showing that some of these small molecules increase reprogramming efficiency and quality, while others (or combinations of them) can fully replace OSKM reprogramming factors.

\section{Clinical and Therapeutic Application of iPSCs}

\subsection{Tissue Regeneration and Cell Transplantation Therapy}

Generation of autologous cells for tissue regeneration and cell transplantation therapy has been the elusive goal of regenerative medicine since the discovery and establishment of the first pluripotent stem cells. Their inherent regenerative properties make them the ideal candidate for cell-based therapies. The self-renewing capacity in combination with their plasticity, hESCs provide significant potential in translational medicine. Nevertheless, due to the controversial source, limitations in efficient differentiation protocols and immunological incompatibility between host and donor cells, the translational progress of hESCs has been limited in cell transplantation therapies. In recent years, the use of iPSCs as alternate sources of embryonic like stem cells has increased in popularity. The somatic cell origin, ease of in vitro expansion and absence of immunological response due to "personalized" cell lines (host derived donor cells) make iPSCs a very appealing alternative to the more controversial hESCs. It has been established that cardiomyocytes derived from human iPSCs are functionally equal to those derived from hESCs [64]. Additionally, they demonstrated the capacity of these iPSCs to differentiate into nodal-, atrial-, and ventricular like phenotypes providing a novel, autologous source of cells for cardiac repair and cardiovascular research. Zhang et al. [65] demonstrated the potential of embryonic stem cells in a rescue of a Hemophilia B mouse model. Due to limitations in transplantation efficiency (reported $0.03 \%-0.5 \%$ ), need for recipient preconditioning and challenges in differentiation and expansion to functional hepatocytes from these mESCs, new methods using iPSCs were explored. iPSCs derived from wild-type mice were obtained and subsequently differentiated into hepatocytes producing coagulation factor IX (FIX) both in vivo and in vitro. The iPSCs derived hepatocytes functionally engrafted into the hepatic parenchyma showed improved FIX clotting activity by $2 \%-3 \%$, demonstrating substantial improvement and potential disease phenotype rescue.

While the work of both $\mathrm{Wu}$ and Zhang provide compelling evidence for the application of iPSCs and the rescue of disease phenotypes, the work of Hanna and co-workers, in 2007 [66] demonstrated the true potential of iPSCs technology through a rescue of a humanized mouse model of sickle cell anemia using iPSCs derived hematopoietic stem cells. iPSCs were derived from tail-tip fibroblasts of mice affected by a hematopoietic genetic mutation modeling human sickle cell anemia. The subsequent iPSCs were then repaired through homologous recombination of the genetic defect. These corrected iPSCs were then expanded in vitro and differentiated to hematopoietic stem cells and finally transplanted into host mice. Correction of the defect was evaluated by electrophoresis for human beta globin proteins A and S (HBA and HBS). Significant levels of HBA were detected while levels of HBS had decreased at the four- and eight-week periods, indicating a rescue of the disease phenotype and restoration of normal hemoglobin levels. 


\subsection{Disease Modeling and Drug Screening}

Definitively, iPSCs represent a potential unlimited source of autologous cells for regenerative medicine. It has been established that iPSCs derived from patients with known genetic disorders can produce cell lines phenocopying the genetic disorder profile. The use of iPSCs in disease modeling allows for the derivation of many cell lines from different organs and tissue sources from which disease etiology and potential drug therapy can be studied.

The large number of studies reporting the use of iPSCs for modeling disease demonstrates indeed, that these disease-specific stem cells offer a unique opportunity to recapitulate the pathologic human condition in vitro, thereby enabling disease investigation and drug development.

Disease-specific iPSC lines were first reported in 2008 from two groups. Dimos et al. [67] generated iPSCs from an 82-year-old woman diagnosed with a familial form of amyotrophic lateral sclerosis (ALS). A second study by Park et al. [68] described the successful derivation of iPSCs from patients affected by different genetic diseases with either a Mendelian or multifactorial inheritance. Since these first two reports, many other studies have demonstrated the valuable use of iPSCs either to modeling disease or screening drugs in vitro. Some examples are reported below and in Table 1.

Table 1. Examples of current, established iPSC lines derived from patient-specific somatic cells that recapitulate various disease phenotypes.

\begin{tabular}{|c|c|c|c|}
\hline Disease Type & Disease & Cell Line Derived & Reference \\
\hline \multirow{8}{*}{ Neurological } & Huntington's Disease (HD) & Fibroblasts & [69] \\
\hline & Parkinson's Disease (PD) & Fibroblasts & [70] \\
\hline & Familial Alzheimer's Disease (AD) & Fibroblasts & [71] \\
\hline & Frontotemporal Dementia (FTD) & Fibroblasts & [72] \\
\hline & Amyotrophic Lateral Sclerosis (ALS) & Fibroblasts & [73-75] \\
\hline & Spinocerebellar Ataxia Type 2 (SCA 2) & Fibroblasts & [76] \\
\hline & Machado-Joseph Disease (MJD) & Fibroblasts & [77] \\
\hline & Rett Syndrome & Fibroblasts & [78] \\
\hline \multirow{8}{*}{$\begin{array}{l}\text { Cardiac/ } \\
\text { Muscular }\end{array}$} & LEOPARD Syndrome & Fibroblasts & [79] \\
\hline & Duchenne Muscular Dystrophy (DMD) & Fibroblasts & [80] \\
\hline & Long QT Syndrome & Fibroblasts & [81] \\
\hline & Pompe Disease & Fibroblasts & {$[82]$} \\
\hline & Arrhythmogenic Right Ventricular Cardiomyopathy (ARVC) & Fibroblasts & {$[83,84]$} \\
\hline & Dilated Cardiomyopathy (CMD) & Fibroblasts & {$[85]$} \\
\hline & Barth Syndrome (BTHS) & Fibroblasts & [86] \\
\hline & Friedreich Ataxia & Fibroblasts & [87] \\
\hline \multirow{8}{*}{ Metabolic } & Alpha-1 Antitrypsin Deficiency (A1ATD) & Fibroblasts & [88] \\
\hline & Familial Hypercholesterolemia (FH) & Fibroblasts & [89] \\
\hline & Glycogen Storage Disease Type 1a (GSD1a) & Fibroblasts & [90] \\
\hline & Glycogen Storage Disease Type 1b (GSD1b) & $\begin{array}{l}\text { Fibroblasts, Hepatic } \\
\text { Cells (nonparenchymal) }\end{array}$ & {$[91]$} \\
\hline & Type 1 Diabetes & Fibroblasts & [92] \\
\hline & Gauchers Disease (GD) & Fibroblasts & [93] \\
\hline & $\begin{array}{c}\text { Mitochondrial Encephalomyopathy, Lactic Acidosis, and } \\
\text { Stroke-like Episodes (MELAS) }\end{array}$ & Fibroblasts & {$[94]$} \\
\hline & Carnitine Palmitoyltransferase II (CPT II) & Fibroblasts & [95] \\
\hline \multirow{6}{*}{ Eye/Retina } & Usher Syndrome (USH) & Keratinocytes & [96] \\
\hline & Retinitis Pigmentosa (RP) & Fibroblasts & [97-99] \\
\hline & Leber Congenital Amaurosis (LCA) & Fibroblasts & {$[100]$} \\
\hline & Gyrate Atrophy (GA) & Fibroblasts & [101] \\
\hline & Best Vitelliform Macular Dystrophy (BVMD) & Fibroblasts & [102] \\
\hline & Age Related Macular Degeneration (AMD) & T-Cells & [103] \\
\hline \multirow{7}{*}{ Blood } & Shwachman-Diamond Syndrome (SDS) & Fibroblasts & [104] \\
\hline & Dyskeratosis Congenita (DKC) & Fibroblasts & {$[105]$} \\
\hline & Familial Platelet Disorder (FPD) & Peripheral T Cells & {$[106]$} \\
\hline & Sickle Cell Disease & MSCs & {$[107,108]$} \\
\hline & $\beta$-Thalassemia & Fibroblasts & [109] \\
\hline & Myeloproliferative Disorders (MPDs) & $\begin{array}{l}\text { Peripheral Blood CD34 } \\
\text { Cells }\end{array}$ & [18] \\
\hline & Myelodysplastic Syndromes (MDS) & Hematopoietic Cells & [17] \\
\hline
\end{tabular}


Table 1. Cont.

\begin{tabular}{cccc}
\hline Disease Type & Disease & Cell Line Derived & Reference \\
\hline \multirow{4}{*}{ Skeletal/Bone } & Fibrodysplasia Ossificans Progressiva & Fibroblasts & {$[110]$} \\
& Menkes Disease (MNK) & Fibroblasts & {$[111]$} \\
& Skeletal Dysplasia (SD) & Fibroblasts & {$[112]$} \\
& Marfan Syndrome (MFS) & Fibroblasts & {$[113]$} \\
& Craniometaphyseal Dysplasia (CDM) & Peripheral Blood & {$[114]$} \\
\hline & & Mononuclear Cells & \\
\hline \multirow{5}{*}{ Cancer } & Pancreatic ductal Adenocarcinoma (PDAC) & Primary PDAC Cells & {$[115]$} \\
& Chronic Myeloid Leukemia (CML) & Primary CML Cells & {$[20,116]$} \\
& Juvenile Myelomonocytic Leukemia (JML) & Primary JML Cells & {$[117]$} \\
& Gastrointestinal Cancer & Gastrointestinal Cancer & {$[21]$} \\
Other & Cells & {$[118]$} \\
\hline & Li-Fraumeni Syndrome (LFS) & Fibroblasts & {$[119]$} \\
& Hutchinson Gilford Progeria & Fibroblasts & {$[120]$} \\
& Primary Ovarian Insufficiency (POI) & Fibroblasts & {$[121]$} \\
\hline
\end{tabular}

iPSCs technology is providing exciting new opportunities in cardiovascular research by creating platforms to study the mechanisms of disease pathogenesis that could lead to new therapies. For instance, iPSCs derived from patients with LEOPARD syndrome, an autosomal-dominant developmental disorder caused by mutation in the PTPN11 gene encoding the SHP2 phosphatase, can recapitulate the hypertrophic cardiomyopathy phenotype of this disease [81]. Moretti et al. [83] derived patient-specific iPSCs from members of a family affected by long-QT syndrome type 1, an autosomal dominant mutation in KCNQ1 gene. Long-QT syndrome is characterized by abnormally prolonged ventricular repolarization phase, ventricular tachycardia. iPSCs derived from long-QT patients could differentiate into functional cardiac myocytes and recapitulated the electrophysiological features of the disorder. These reprogramming approaches hold promise as a potential application for regenerative medicine as well as preclinical drug and toxicity screenings in the cardiac field.

Parkinson's disease (PD) is a devastating and progressive neuro-degenerative disorder characterized by the loss of neurons in the peripheral and central nervous system. Mutation or duplication/triplications of the $\alpha$-synuclein gene (SNCA) are associated with the familial autosomal forms of PD [122,123]. iPSC-derived midbrain dopaminergic neurons from PD patients, carrying the SNCA triplication, exhibit the signature disease-related phenotype, characterized by accumulation of $\alpha$-synuclein and susceptibility to oxidative stress [70].

Furthermore, studies have shown iPSCs to recapitulate signature pathological phenotypes of inherited metabolic disorders of the liver [90]. Ghodsizadeh et al. [22] reported the first successful derivation of functional liver disease-specific iPSC lines from patients' fibroblasts.

Successful examples of iPSCs modeling skeletal genetic diseases have been reported for Marfan syndrome (MFS), an autosomal dominant disorder of connective tissue caused by mutations in the gene coding for Fibrillin-1 (FBN-1). A study by Quarto et al. [113] demonstrated that iPSCs derived from MFS patient fibroblasts faithfully phenocopied the skeletogenic profile observed in hESC carrying the same monogenic FBN1 mutation. This study provided the first evidence that in vitro iPSC models can be used to dissect molecular mechanisms underlying MFS syndrome [124].

The dominantly inherited Skeletal Dysplasias (SDs) is characterized by abnormal chondrogenesis during cartilage growth plate differentiation caused by mutation of the TRPV4 gene encoding the transient receptor potential vanilloid family member 4 , calcium channel protein. iPSCs derived from SD patients can recapitulate dysregulated processes of aberrant chondrogenic developmental, thus modeling the disease and providing a potential tool to design therapeutic approaches for disorders of cartilage [112].

Nonetheless, the ultimate utility of iPSCs will be for drug screening and identification of novel pathways critical to rescue diseases. Dyskeratosis Congenita (DC) is a telomere disorder resulting in degeneration of multiple tissues types [125]. In their study, Agarwal et al. [126] reported that 
reprogramming DC somatic cells into iPSCs restores telomere elongation in these cells despite genetic lesions affecting telomerase, thus showing a rescue of the disease phenotype in DC cells. Furthermore, this study also indicated that activation of pluripotency-associated transcription factors like OSKM, which often target telomerase components (TERC) leading to the self-renewing characteristics of ESCs, may be a strategy therapeutically beneficial in DC patients. Activation of these transcription factors through reprogramming techniques in DC cells restored telomerase RNA component (TERC) levels and normal telomere maintenance. In this example, the use and derivation of iPSCs from patients exhibiting DC revealed a novel pathway resulting in the disease phenotype and provided a potential rescue, therefore suggesting, that drugs increasing TERC expression could be of therapeutic value to DC patients. Thus, iPSCs provide a method to bridge the gap between mouse models, which can be inaccurate or not translational, and human clinical studies, which are extremely expensive, time consuming and strictly regulated. In this context, the use of iPSCs to model and subsequently study disease pathology, small molecule screening and drug development, could represent a transforming tool in modern pharmacology.

\section{Limitations and Concerns of Current iPSCs Technology}

While recent research has made clear the potential application of iPSCs technology in translational medicine, there are still significant concerns associated with the reprogramming of adult somatic cells that must be addressed before the mainstream use of this technology. The long-term effects of an induced pluripotent state are still unclear. The changes associated with reprogramming, such as activation of oncogenes and tumor suppressor genes, the risk of cancer or teratocarcinoma formation and the lack of robust and effective differentiation protocols all pose significant challenges to the use of iPSCs as cell based therapies for human patients.

\subsection{Functionality}

One of the major obstacles hindering widespread use of iPSCs technology is the lack of efficient and at times complete differentiation of immature iPSCs to mature somatic cells needed for therapeutic purposes. Most current and successful studies have been centered on the differentiation and use of hematopoietic cells, neurons or cardiomyocytes-the easiest cells to differentiate from iPSCs. However, many other cell lines are of therapeutic value and current protocols do not always work, delivering low yield with significant differences in potency at maturity. Bao-Yang et al. [127] demonstrated that iPSCs displayed vast variability in their neural differentiation capacity, between $15 \%-79 \%$ as compared to $90 \%-97 \%$ from hESCs. It is important to note that through transcriptional analysis, the differentiation pathways were conserved between ESCs and iPSCs. Variability was maintained regardless of reprogramming technique, through multiple different iPSC lines, demonstrating the potential basis of these differences in potency to be the innate nature of the two types of pluripotent cell lines. This lack of robust and effective differentiation of iPSCs is highly concerning from a clinical standpoint, as the transplantation of immature cells could result in the development of cancers or teratocarcinoma. In a recent study signifying epigenetic memory could potentially improve differentiation procedures, Sanches-Freire et al. [128] demonstrated iPSCs derived from cardiac progenitors cells $v s$. fibroblasts showed increased efficiency in differentiation to cardiomyocytes, but remained functionally equivalent in vivo. Efforts toward improved differentiation protocols, potentially harnessing the utility of epigenetic programing as a form of "pre-conditioning", could provide tangible solutions to the current limitations of iPSCs technology.

\subsection{Chromosomal Aberrations and Genetic Modifications}

From an outward appearance, iPSCs are thought to be analogous to ESCs, identical in make-up and functionality. Conversely, current understanding of both these pluripotent cell lines states otherwise. Advances in high-resolution genetic analysis has uncovered some subtle and not so subtle differences between these two cells lines. Current pluripotent stem cell technology, including both ESCs and iPSCs 
are greatly limited in their translational application due to fear of cancer development. Much is still unknown of the long-term effect of reprogramming methods, differentiation and expansion in vitro. Residual integration of reprograming components has limited iPSCs technology in cell-based therapy, though many efforts have been made towards generating non-intergrating reprograming protocols. Differentiation and expansion of these pluripotent cells lines is still dependent on in vitro culturing resulting in selective pressures for enhanced survival and proliferation. These concerns among many other chromosomal aberrations have severely hindered the use of iPSCs in clinical applications. Chin et al. [129], demonstrated that iPSCs have a novel and signature gene expression pattern unique from ESCs, but conserved between iPSCs derived from different species and reprograming techniques. Through a series of extensive analysis including array Comparative Genomic Hybridization (CGH), coding RNA profiling, miRNA profiling and histone modifications, this specific gene expression pattern found 3947 of 17,620 genes with differential expression levels between iPSCs and hESCs. Of these differences, $79 \%$ were suppressed; these genes correlated to energy production, RNA processing, DNA repair and mitosis. Furthermore, those upregulated in iPSCs relative to ESCs were implicated in differentiation [129]. These results are indicative of an inefficient silenced expression pattern of the parent somatic cell or insufficient induction of ESC genes, demonstrating genetic disparities between iPSCs and ESCs despite similarities in vivo. Further studies demonstrate that DNA methylation, a primary mechanism of epigenetic transcriptional regulation shows variation between iPSCs and hESCs [130]; iPSCs showed increased methylation as compared to hESCs implying differential gene regulation and epigenetics. The impact of these genetic changes is still unclear and many questions need to be answered before iPSCs are of use from a clinical perspective.

\subsection{Cancer and Terotocarcinoma Formation}

Cancer and/or the formations of teratocarcinomas are concern of iPSCs-based therapies. The introduction of cells of varying potency with manipulated gene expression is of great concern from the clinical perspective. For this reason, extensive studies must be conducted on the genetic and chromosomal aberrations that take place during reprogramming, in vitro expansion and differentiation. Through the technique of high resolution Single Nucleotide Polymorphism (SNP) Analysis, it was demonstrated that reprogramming of somatic cells to iPSCs is associated with the deletion of tumors suppressing genes during the time of differentiation, and expansion was associated with duplication of oncogenes [131]. Furthermore, full or partial chromosome aberrations, including a novel aneuploidy have been observed in early passage iPSCs. Mayshar et al. [132] reported a high incident of chromosome 12 duplications and significant enrichment of cell cycle-related genes implying limited differentiation and increase tumorigenicity. Lee et al. [133] demonstrated the disruption of control mechanism of Transposable Elements (TE) could facilitate retroactive transposons resulting in cancer. Similarly, Shukla showed a specific TE, Line-1 (L1) retro-transposons to be implicated in tumorigenesis in hepatocellular carcinoma. When Line- 1 activity was compared in iPSCs to its parent cells, it was found to have increased by orders of magnitude, demonstrating reprogramming techniques significantly increase the risk of genetic instability and potential for cancer development [134].

\subsection{Immunogenicity}

Although it is widely assumed that autologous iPSCs and their derivatives should be immunologically tolerated by the recipient, the immunogenicity of iPSCs derivatives remains very controversial and quite complicated. The immunogenicity of iPSCs has been controversial since the original report that syngeneic mouse iPSCs elicited an immune response after transplantation [135]. Several studies suggest that both genetic and epigenetic defects occurring randomly during somatic reprogramming can directly or indirectly contribute to the immunogenicity of iPSCs derivatives [136-138]. Additional potential causes of iPSCs immunogenicity is immaturity of cells differentiated from iPSCs in vitro [139], and culturing of iPSCs, or their differentiated progeny, with xenogeneic or non-physiological culture reagents [140]. 
Zhao and colleagues found a subpopulation of cells derived from mouse iPSCs to be immunogenic, and the immune rejection $T$ cell dependent [135]. In this study two genes were identified, Hormad1 and Zg16, as abnormally expressed in iPSCs-teratoma but not in ES-teratoma, being directly responsible for the immunogenicity of iPSCs derivatives. In contrast, other studies suggested that the integration-free human iPSCs has low or negligible immunogenicity [141,142]. Morizane et al. [143] performed autologous iPSC-derived neural cell transplantation in a primate model and also found minimal evidence of chronic immune response in the brain. Although further confirmatory work is necessary, these latter studies are encouraging. In general, compared to allograft, the immunogenicity of autologous iPSC derivatives is much weaker. A recent study demonstrated that the immune response towards antigens of iPSCs is dependent on the immune environment of the transplantation site [144]. Understanding the risk of an immune response and developing strategies to minimize it will indeed be important steps before clinical application of iPSCs.

\section{Concluding Remarks}

The breakthrough discovery of iPSCs has greatly reshaped the scientific and political landscapes of stem cell biology. This discovery is a remarkable achievement for research and potential therapy. The ease of their derivation, capacity for rapid and robust expansion in vitro, ESC-like characteristics, minimal immune response due to patient matched cell lines and most importantly, their plentiful and uncontroversial source, make iPSCs an ideal replacement for hESCs in translational medicine. Because of fewer ethical restrictions and readily accessible donor tissue, additional research opportunities, both basic and translational, will be further performed to better understand the nature of iPSCs. However, as addressed in this review, recent research has brought to light significant differences between iPSCs and ESCs at the genomic level causing great concern in their translational application, particularly as cell-based therapies. During reprogramming, chromosomal aberrations can result in the deletion of tumor suppressor genes and duplication of oncogenes. These oncogenes are often highly selected for during in vitro expansion and differentiation [129]. Moreover, transplantation of these cells to human patients could lead to cancer, a significant limitation from a clinical perspective. It is not clear if reprograming techniques efficiently suppress parent somatic cell genes while inducing ESC genes. The result of this "incomplete" reprogramming is not fully understood, but thought to give varying levels of differentiation and potency to these cells. The transplantation of immature cells could again result in cancer or teratocarcinoma formation limiting their translational application. As improved reprogramming and differentiation protocols are developed, the use of iPSCs in disease modeling and drug discovery will be more applicable. Current techniques produce disease phenotypes, however, the extent of recapitulating all aspects of the disease is still limited. Overall, the vast potential of iPSCs in cell-based therapeutics, drug discovery and disease modeling is clear, though significantly hindered by the lack of understanding of the long-term risks. Until more is understood about the mechanisms of induced pluripotency and differentiation, and the development of extensive screening procedures for genetic aberrations resulting in stable genomes, the use of iPSCs technology remains inadequate for most translational medicine and clinical applications.

Acknowledgments: This work was supported by the Oak Foundation, the Gunn/Olivier fund, the Hagey Laboratory for Pediatric Regenerative Medicine, the National Institutes of Health NIH grants R01 DE021683-01, R01 DE19434, U01HL099776 to Michael Longaker “Transplant and Tissue Engineering Program Endowment Awards "Lucille Packard Children Hospital Translational Medicine/Transplant" Stanford University to Natalina Quarto.

Author Contributions: Siddharth Menon: manuscript writing and illustrations; Siny Shailendra and Natalina Quarto writing of manuscript; Michael Longaker and Andrea Renda editing of manuscript.

Conflicts of Interest: The authors declare no conflict of interest. 


\section{References}

1. Evans, M.J.; Kaufman, M.H. Establishment in culture of pluripotential cells from mouse embryos. Nature 1981, 292, 154-156. [CrossRef] [PubMed]

2. Martin, G.R. Isolation of a pluripotent cell line from early mouse embryos cultured in medium conditioned by teratocarcinoma stem cells. Proc. Natl. Acad. Sci. USA 1981, 78, 7634-7638. [CrossRef] [PubMed]

3. Thomson, J.A.; Itskovitz-Eldor, J.; Shapiro, S.S.; Waknitz, M.A.; Swiergiel, J.J.; Marshall, V.S.; Jones, J.M. Embryonic stem cell lines derived from human blastocysts. Science 1998, 282, 1145-1147. [CrossRef] [PubMed]

4. Tesar, P.J.; Chenoweth, J.G.; Brook, F.A.; Davies, T.J.; Evans, E.P.; Mack, D.L.; Gardner, R.L.; McKay, R.D. New cell lines from mouse epiblast share defining features with human embryonic stem cells. Nature 2007, 448, 196-199. [CrossRef] [PubMed]

5. Mendez-Ferrer, S.; Scadden, D.T.; Sanchez-Aguilera, A. Bone marrow stem cells: Current and emerging concepts. Ann. N. Y. Acad. Sci. 2015, 1335, 32-44. [CrossRef] [PubMed]

6. Senarath-Yapa, K.; McArdle, A.; Renda, A.; Longaker, M.T.; Quarto, N. Adipose-derived stem cells: A review of signaling networks governing cell fate and regenerative potential in the context of craniofacial and long bone skeletal repair. Int. J. Mol. Sci. 2014, 15, 9314-9330. [CrossRef] [PubMed]

7. Weissman, I.L.; Shizuru, J.A. The origins of the identification and isolation of hematopoietic stem cells, and their capability to induce donor-specific transplantation tolerance and treat autoimmune diseases. Blood 2008, 112, 3543-3553. [CrossRef] [PubMed]

8. Takahashi, K.; Yamanaka, S. Induction of pluripotent stem cells from mouse embryonic and adult fibroblast cultures by defined factors. Cell 2006, 126, 663-676. [CrossRef] [PubMed]

9. Notarianni, E.; Galli, C.; Laurie, S.; Moor, R.M.; Evans, M.J. Derivation of pluripotent, embryonic cell lines from the pig and sheep. J. Reprod. Fertil. Suppl. 1991, 43, 255-260. [PubMed]

10. Gurdon, J.B.; Elsdale, T.R.; Fischberg, M. Sexually mature individuals of Xenopus laevis from the transplantation of single somatic nuclei. Nature 1958, 182, 64-65. [CrossRef] [PubMed]

11. Briggs, R.; King, T.J. Transplantation of living nuclei from blastula cells into enucleated frogs' eggs. Proc. Natl. Acad. Sci. USA 1952, 38, 455-463. [CrossRef] [PubMed]

12. Takahashi, K.; Yamanaka, S. A developmental framework for induced pluripotency. Development 2015, 142, 3274-3285. [CrossRef] [PubMed]

13. Takahashi, K.; Tanabe, K.; Ohnuki, M.; Narita, M.; Ichisaka, T.; Tomoda, K.; Yamanaka, S. Induction of pluripotent stem cells from adult human fibroblasts by defined factors. Cell 2007, 131, 861-872. [CrossRef] [PubMed]

14. Cassady, J.P.; D'Alessio, A.C.; Sarkar, S.; Dani, V.S.; Fan, Z.P.; Ganz, K.; Roessler, R.; Sur, M.; Young, R.A.; Jaenisch, R. Direct lineage conversion of adult mouse liver cells and B lymphocytes to neural stem cells. Stem Cell Rep. 2014, 3, 948-956. [CrossRef] [PubMed]

15. Aasen, T.; Izpisua Belmonte, J.C. Isolation and cultivation of human keratinocytes from skin or plucked hair for the generation of induced pluripotent stem cells. Nat. Protoc. 2010, 5, 371-382. [CrossRef] [PubMed]

16. Aasen, T.; Raya, A.; Barrero, M.J.; Garreta, E.; Consiglio, A.; Gonzalez, F.; Vassena, R.; Bilic, J.; Pekarik, V.; Tiscornia, G.; et al. Efficient and rapid generation of induced pluripotent stem cells from human keratinocytes. Nat. Biotechnol. 2008, 26, 1276-1284. [CrossRef] [PubMed]

17. Kotini, A.G.; Chang, C.J.; Boussaad, I.; Delrow, J.J.; Dolezal, E.K.; Nagulapally, A.B.; Perna, F.; Fishbein, G.A.; Klimek, V.M.; Hawkins, R.D.; et al. Functional analysis of a chromosomal deletion associated with myelodysplastic syndromes using isogenic human induced pluripotent stem cells. Nat. Biotechnol. 2015, 33, 646-655. [CrossRef] [PubMed]

18. Ye, Z.; Zhan, H.; Mali, P.; Dowey, S.; Williams, D.M.; Jang, Y.Y.; Dang, C.V.; Spivak, J.L.; Moliterno, A.R.; Cheng, L. Human-induced pluripotent stem cells from blood cells of healthy donors and patients with acquired blood disorders. Blood 2009, 114, 5473-5480. [CrossRef] [PubMed]

19. Yi, F.; Liu, G.H.; Izpisua Belmonte, J.C. Human induced pluripotent stem cells derived hepatocytes: Rising promise for disease modeling, drug development and cell therapy. Protein Cell 2012, 3, 246-250. [CrossRef] [PubMed] 
20. Kumano, K.; Arai, S.; Hosoi, M.; Taoka, K.; Takayama, N.; Otsu, M.; Nagae, G.; Ueda, K.; Nakazaki, K.; Kamikubo, Y.; et al. Generation of induced pluripotent stem cells from primary chronic myelogenous leukemia patient samples. Blood 2012, 119, 6234-6242. [CrossRef] [PubMed]

21. Miyoshi, N.; Ishii, H.; Nagai, K.; Hoshino, H.; Mimori, K.; Tanaka, F.; Nagano, H.; Sekimoto, M.; Doki, Y.; Mori, M. Defined factors induce reprogramming of gastrointestinal cancer cells. Proc. Natl. Acad. Sci. USA 2010, 107, 40-45. [CrossRef] [PubMed]

22. Ghodsizadeh, A.; Taei, A.; Totonchi, M.; Seifinejad, A.; Gourabi, H.; Pournasr, B.; Aghdami, N.; Malekzadeh, R.; Almadani, N.; Salekdeh, G.H.; et al. Generation of liver disease-specific induced pluripotent stem cells along with efficient differentiation to functional hepatocyte-like cells. Stem Cell Rev. 2010, 6, 622-632. [CrossRef] [PubMed]

23. Gonzalez, F.; Boue, S.; Izpisua Belmonte, J.C. Methods for making induced pluripotent stem cells: Reprogramming a la carte. Nat. Rev. Genet. 2011, 12, 231-242. [CrossRef] [PubMed]

24. Seifinejad, A.; Tabebordbar, M.; Baharvand, H.; Boyer, L.A.; Salekdeh, G.H. Progress and promise towards safe induced pluripotent stem cells for therapy. Stem Cell Rev. 2010, 6, 297-306. [CrossRef] [PubMed]

25. Wu, J.; Izpisua Belmonte, J.C. Dynamic pluripotent stem cell states and their applications. Cell Stem Cell 2015, 17, 509-525. [CrossRef] [PubMed]

26. Nakagawa, M.; Koyanagi, M.; Tanabe, K.; Takahashi, K.; Ichisaka, T.; Aoi, T.; Okita, K.; Mochiduki, Y.; Takizawa, N.; Yamanaka, S. Generation of induced pluripotent stem cells without Myc from mouse and human fibroblasts. Nat. Biotechnol. 2008, 26, 101-106. [CrossRef] [PubMed]

27. Markoulaki, S.; Hanna, J.; Beard, C.; Carey, B.W.; Cheng, A.W.; Lengner, C.J.; Dausman, J.A.; Fu, D.; Gao, Q.; Wu, S.; et al. Transgenic mice with defined combinations of drug-inducible reprogramming factors. Nat. Biotechnol. 2009, 27, 169-171. [CrossRef] [PubMed]

28. Okita, K.; Ichisaka, T.; Yamanaka, S. Generation of germline-competent induced pluripotent stem cells. Nature 2007, 448, 313-317. [CrossRef] [PubMed]

29. Wernig, M.; Meissner, A.; Cassady, J.P.; Jaenisch, R. c-Myc is dispensable for direct reprogramming of mouse fibroblasts. Cell Stem Cell 2008, 2, 10-12. [CrossRef] [PubMed]

30. Aoi, T.; Nakagawa, M.; Ichisaka, T.; Okita, K.; Takahashi, K.; Chiba, T.; Yamanaka, S. Generation of pluripotent stem cells from adult mouse liver and stomach cells. Science 2008, 321, 699-702. [CrossRef] [PubMed]

31. Stadtfeld, M.; Nagaya, M.; Utikal, J.; Weir, G.; Hochedlinger, K. Induced pluripotent stem cells generated without viral integration. Science 2008, 322, 945-949. [CrossRef] [PubMed]

32. Chang, C.W.; Lai, Y.S.; Pawlik, K.M.; Liu, K.; Sun, C.W.; Li, C.; Schoeb, T.R.; Townes, T.M. Polycistronic lentiviral vector for "hit and run" reprogramming of adult skin fibroblasts to induced pluripotent stem cells. Stem Cells 2009, 27, 1042-1049. [CrossRef] [PubMed]

33. Woodard, L.E.; Wilson, M.H. PiggyBac-ing models and new therapeutic strategies. Trends Biotechnol. 2015, 33, 525-533. [CrossRef] [PubMed]

34. Woltjen, K.; Michael, I.P.; Mohseni, P.; Desai, R.; Mileikovsky, M.; Hamalainen, R.; Cowling, R.; Wang, W.; Liu, P.; Gertsenstein, M.; et al. PiggyBac transposition reprograms fibroblasts to induced pluripotent stem cells. Nature 2009, 458, 766-770. [CrossRef] [PubMed]

35. Kaji, K.; Norrby, K.; Paca, A.; Mileikovsky, M.; Mohseni, P.; Woltjen, K. Virus-free induction of pluripotency and subsequent excision of reprogramming factors. Nature 2009, 458, 771-775. [CrossRef] [PubMed]

36. Medvedev, S.P.; Shevchenko, A.I.; Zakian, S.M. Induced pluripotent stem cells: Problems and advantages when applying them in regenerative medicine. Acta Naturae 2010, 2, 18-28. [PubMed]

37. Graham, F.L.; Prevec, L. Adenovirus-based expression vectors and recombinant vaccines. Biotechnology 1992, 20, 363-390. [PubMed]

38. He, T.C.; Zhou, S.; da Costa, L.T.; Yu, J.; Kinzler, K.W.; Vogelstein, B. A simplified system for generating recombinant adenoviruses. Proc. Natl. Acad. Sci. USA 1998, 95, 2509-2514. [CrossRef] [PubMed]

39. Zhou, W.; Freed, C.R. Adenoviral gene delivery can reprogram human fibroblasts to induced pluripotent stem cells. Stem Cells 2009, 27, 2667-2674. [CrossRef] [PubMed]

40. Narsinh, K.H.; Jia, F.; Robbins, R.C.; Kay, M.A.; Longaker, M.T.; Wu, J.C. Generation of adult human induced pluripotent stem cells using nonviral minicircle DNA vectors. Nat. Protoc. 2011, 6, 78-88. [CrossRef] [PubMed] 
41. Meraviglia, V.; Zanon, A.; Lavdas, A.A.; Schwienbacher, C.; Silipigni, R.; di Segni, M.; Chen, H.S.; Pramstaller, P.P.; Hicks, A.A.; Rossini, A. Generation of induced pluripotent stem cells from frozen buffy coats using non-integrating episomal plasmids. J. Vis. Exp. 2015, e52885.

42. Hu, W.; He, Y.; Xiong, Y.; Lu, H.; Chen, H.; Hou, L.; Qiu, Z.; Fang, Y.; Zhang, S. Derivation, expansion, and motor neuron differentiation of human-induced pluripotent stem cells with non-integrating episomal vectors and a defined Xenogeneic-free culture system. Mol. Neurobiol. 2015. [CrossRef] [PubMed]

43. Okita, K.; Yamakawa, T.; Matsumura, Y.; Sato, Y.; Amano, N.; Watanabe, A.; Goshima, N.; Yamanaka, S. An efficient nonviral method to generate integration-free human-induced pluripotent stem cells from cord blood and peripheral blood cells. Stem Cells 2013, 31, 458-466. [CrossRef] [PubMed]

44. Cheng, L.; Hansen, N.F.; Zhao, L.; Du, Y.; Zou, C.; Donovan, F.X.; Chou, B.K.; Zhou, G.; Li, S.; Dowey, S.N.; et al. Low incidence of DNA sequence variation in human induced pluripotent stem cells generated by nonintegrating plasmid expression. Cell Stem Cell 2012, 10, 337-344. [CrossRef] [PubMed]

45. Fusaki, N.; Ban, H.; Nishiyama, A.; Saeki, K.; Hasegawa, M. Efficient induction of transgene-free human pluripotent stem cells using a vector based on Sendai virus, an RNA virus that does not integrate into the host genome. Proc. Jpn. Acad. Ser. B Phys. Biol. Sci. 2009, 85, 348-362. [CrossRef] [PubMed]

46. Liu, J.; Verma, P.J. Synthetic mRNA reprogramming of human fibroblast cells. Methods Mol. Biol. 2015, 1330, 17-28. [PubMed]

47. Warren, L.; Manos, P.D.; Ahfeldt, T.; Loh, Y.H.; Li, H.; Lau, F.; Ebina, W.; Mandal, P.K.; Smith, Z.D.; Meissner, A.; et al. Highly efficient reprogramming to pluripotency and directed differentiation of human cells with synthetic modified mRNA. Cell Stem Cell 2010, 7, 618-630. [CrossRef] [PubMed]

48. Miyoshi, N.; Ishii, H.; Nagano, H.; Haraguchi, N.; Dewi, D.L.; Kano, Y.; Nishikawa, S.; Tanemura, M.; Mimori, K.; Tanaka, F.; et al. Reprogramming of mouse and human cells to pluripotency using mature microRNAs. Cell Stem Cell 2011, 8, 633-638. [CrossRef] [PubMed]

49. Sandmaier, S.E.; Telugu, B.P. MicroRNA-mediated reprogramming of somatic cells into induced pluripotent stem cells. Methods Mol. Biol. 2015, 1330, 29-36. [PubMed]

50. Zhou, H.; Wu, S.; Joo, J.Y.; Zhu, S.; Han, D.W.; Lin, T.; Trauger, S.; Bien, G.; Yao, S.; Zhu, Y.; et al. Generation of induced pluripotent stem cells using recombinant proteins. Cell Stem Cell 2009, 4, 381-384. [CrossRef] [PubMed]

51. Kim, D.; Kim, C.H.; Moon, J.I.; Chung, Y.G.; Chang, M.Y.; Han, B.S.; Ko, S.; Yang, E.; Cha, K.Y.; Lanza, R.; et al. Generation of human induced pluripotent stem cells by direct delivery of reprogramming proteins. Cell Stem Cell 2009, 4, 472-476. [CrossRef] [PubMed]

52. Belting, M.; Sandgren, S.; Wittrup, A. Nuclear delivery of macromolecules: Barriers and carriers. Adv. Drug Deliv. Rev. 2005, 57, 505-527. [CrossRef] [PubMed]

53. El-Sayed, A.; Futaki, S.; Harashima, H. Delivery of macromolecules using arginine-rich cell-penetrating peptides: Ways to overcome endosomal entrapment. AAPS J. 2009, 11, 13-22. [CrossRef] [PubMed]

54. Ziegler, A.; Nervi, P.; Durrenberger, M.; Seelig, J. The cationic cell-penetrating peptide CPP (TAT) derived from the HIV-1 protein TAT is rapidly transported into living fibroblasts: Optical, biophysical, and metabolic evidence. Biochemistry 2005, 44, 138-148. [CrossRef] [PubMed]

55. Nie, B.; Wang, H.; Laurent, T.; Ding, S. Cellular reprogramming: A small molecule perspective. Curr. Opin. Cell Biol. 2012, 24, 784-792. [CrossRef] [PubMed]

56. Huangfu, D.; Maehr, R.; Guo, W.; Eijkelenboom, A.; Snitow, M.; Chen, A.E.; Melton, D.A. Induction of pluripotent stem cells by defined factors is greatly improved by small-molecule compounds. Nat. Biotechnol. 2008, 26, 795-797. [CrossRef] [PubMed]

57. Li, Y.; Zhang, Q.; Yin, X.; Yang, W.; Du, Y.; Hou, P.; Ge, J.; Liu, C.; Zhang, W.; Zhang, X.; et al. Generation of iPSCs from mouse fibroblasts with a single gene, Oct4, and small molecules. Cell Res. 2011, 21, 196-204. [CrossRef] [PubMed]

58. Li, Z.; Rana, T.M. A kinase inhibitor screen identifies small-molecule enhancers of reprogramming and iPS cell generation. Nat. Commun. 2012, 3. [CrossRef] [PubMed]

59. Li, X.; Zuo, X.; Jing, J.; Ma, Y.; Wang, J.; Liu, D.; Zhu, J.; Du, X.; Xiong, L.; Du, Y.; et al. Small-molecule-driven direct reprogramming of mouse fibroblasts into functional neurons. Cell Stem Cell 2015, 17, 195-203. [CrossRef] [PubMed] 
60. Liu, M.L.; Zang, T.; Zou, Y.; Chang, J.C.; Gibson, J.R.; Huber, K.M.; Zhang, C.L. Small molecules enable neurogenin 2 to efficiently convert human fibroblasts into cholinergic neurons. Nat. Commun. 2013, 4. [CrossRef] [PubMed]

61. Cheng, L.; Hu, W.; Qiu, B.; Zhao, J.; Yu, Y.; Guan, W.; Wang, M.; Yang, W.; Pei, G. Generation of neural progenitor cells by chemical cocktails and hypoxia. Cell Res. 2014, 24, 665-679. [CrossRef] [PubMed]

62. Ladewig, J.; Mertens, J.; Kesavan, J.; Doerr, J.; Poppe, D.; Glaue, F.; Herms, S.; Wernet, P.; Kogler, G.; Muller, F.J.; et al. Small molecules enable highly efficient neuronal conversion of human fibroblasts. Nat. Methods 2012, 9, 575-578. [CrossRef] [PubMed]

63. Zhu, S.; Li, W.; Zhou, H.; Wei, W.; Ambasudhan, R.; Lin, T.; Kim, J.; Zhang, K.; Ding, S. Reprogramming of human primary somatic cells by OCT4 and chemical compounds. Cell Stem Cell 2010, 7, 651-655. [CrossRef] [PubMed]

64. Zhang, J.; Wilson, G.F.; Soerens, A.G.; Koonce, C.H.; Yu, J.; Palecek, S.P.; Thomson, J.A.; Kamp, T.J. Functional cardiomyocytes derived from human induced pluripotent stem cells. Circ. Res. 2009, 104, e30-e41. [CrossRef] [PubMed]

65. Wu, Y.M.; Huang, Y.J.; Chen, P.; Hsu, Y.C.; Lin, S.W.; Lai, H.; Lee, H.S. Hepatocyte-like cells derived from mouse induced pluripotent stem cells produce functional coagulation factor IX in a hemophilia B mouse model. Cell Transpl. 2015. [CrossRef]

66. Hanna, J.; Wernig, M.; Markoulaki, S.; Sun, C.W.; Meissner, A.; Cassady, J.P.; Beard, C.; Brambrink, T.; Wu, L.C.; Townes, T.M.; et al. Treatment of sickle cell anemia mouse model with iPS cells generated from autologous skin. Science 2007, 318, 1920-1923. [CrossRef] [PubMed]

67. Dimos, J.T.; Rodolfa, K.T.; Niakan, K.K.; Weisenthal, L.M.; Mitsumoto, H.; Chung, W.; Croft, G.F.; Saphier, G.; Leibel, R.; Goland, R.; et al. Induced pluripotent stem cells generated from patients with ALS can be differentiated into motor neurons. Science 2008, 321, 1218-1221. [CrossRef] [PubMed]

68. Park, I.H.; Arora, N.; Huo, H.; Maherali, N.; Ahfeldt, T.; Shimamura, A.; Lensch, M.W.; Cowan, C.; Hochedlinger, K.; Daley, G.Q. Disease-specific induced pluripotent stem cells. Cell 2008, 134, 877-886. [CrossRef] [PubMed]

69. Consortium, H.D.i. Induced pluripotent stem cells from patients with huntington's disease show cag-repeat-expansion-associated phenotypes. Cell Stem Cell 2012, 11, 264-278.

70. Byers, B.; Cord, B.; Nguyen, H.N.; Schule, B.; Fenno, L.; Lee, P.C.; Deisseroth, K.; Langston, J.W.; Pera, R.R.; Palmer, T.D. SNCA triplication Parkinson's patient's iPSC-derived Da neurons accumulate $\alpha$-synuclein and are susceptible to oxidative stress. PLoS ONE 2011, 6, e26159. [CrossRef] [PubMed]

71. Soldner, F.; Hockemeyer, D.; Beard, C.; Gao, Q.; Bell, G.W.; Cook, E.G.; Hargus, G.; Blak, A.; Cooper, O.; Mitalipova, M.; et al. Parkinson's disease patient-derived induced pluripotent stem cells free of viral reprogramming factors. Cell. 2009, 136, 964-977. [CrossRef] [PubMed]

72. Israel, M.A.; Yuan, S.H.; Bardy, C.; Reyna, S.M.; Mu, Y.; Herrera, C.; Hefferan, M.P.; van Gorp, S.; Nazor, K.L.; Boscolo, F.S.; et al. Probing sporadic and familial Alzheimer's disease using induced pluripotent stem cells. Nature 2012, 482, 216-220. [PubMed]

73. Almeida, S.; Gascon, E.; Tran, H.; Chou, H.J.; Gendron, T.F.; Degroot, S.; Tapper, A.R.; Sellier, C.; Charlet-Berguerand, N.; Karydas, A.; et al. Modeling key pathological features of frontotemporal dementia with C9ORF72 repeat expansion in iPSC-derived human neurons. Acta Neuropathol. 2013, 126, 385-399. [CrossRef] [PubMed]

74. Almeida, S.; Zhang, Z.; Coppola, G.; Mao, W.; Futai, K.; Karydas, A.; Geschwind, M.D.; Tartaglia, M.C.; Gao, F.; Gianni, D.; et al. Induced pluripotent stem cell models of progranulin-deficient frontotemporal dementia uncover specific reversible neuronal defects. Cell Rep. 2012, 2, 789-798. [CrossRef] [PubMed]

75. Li, Y.; Balasubramanian, U.; Cohen, D.; Zhang, P.W.; Mosmiller, E.; Sattler, R.; Maragakis, N.J.; Rothstein, J.D. A comprehensive library of familial human amyotrophic lateral sclerosis induced pluripotent stem cells. PLoS ONE 2015, 10, e0118266. [CrossRef] [PubMed]

76. Chen, H.; Qian, K.; Du, Z.; Cao, J.; Petersen, A.; Liu, H.; Blackbourn, L.W.T.; Huang, C.L.; Errigo, A.; Yin, Y.; et al. Modeling als with iPSCs reveals that mutant SOD1 misregulates neurofilament balance in motor neurons. Cell Stem Cell 2014, 14, 796-809. [CrossRef] [PubMed]

77. Egawa, N.; Kitaoka, S.; Tsukita, K.; Naitoh, M.; Takahashi, K.; Yamamoto, T.; Adachi, F.; Kondo, T.; Okita, K.; Asaka, I.; et al. Drug screening for ALS using patient-specific induced pluripotent stem cells. Sci Transl Med. 2012, 4, 145ra104. [CrossRef] [PubMed] 
78. Xia, G.; Santostefano, K.; Hamazaki, T.; Liu, J.; Subramony, S.H.; Terada, N.; Ashizawa, T. Generation of human-induced pluripotent stem cells to model spinocerebellar ataxia type 2 in vitro. J. Mol. Neurosci. 2013, 51, 237-248. [CrossRef] [PubMed]

79. Koch, P.; Breuer, P.; Peitz, M.; Jungverdorben, J.; Kesavan, J.; Poppe, D.; Doerr, J.; Ladewig, J.; Mertens, J.; Tuting, T.; et al. Excitation-induced ataxin-3 aggregation in neurons from patients with machado-joseph disease. Nature 2011, 480, 543-546. [CrossRef] [PubMed]

80. Djuric, U.; Cheung, A.Y.; Zhang, W.; Mok, R.S.; Lai, W.; Piekna, A.; Hendry, J.A.; Ross, P.J.; Pasceri, P.; Kim, D.S.; et al. MECP2E1 isoform mutation affects the form and function of neurons derived from rett syndrome patient ips cells. Neurobiol. Dis. 2015, 76, 37-45. [CrossRef] [PubMed]

81. Carvajal-Vergara, X.; Sevilla, A.; D'Souza, S.L.; Ang, Y.S.; Schaniel, C.; Lee, D.F.; Yang, L.; Kaplan, A.D.; Adler, E.D.; Rozov, R.; et al. Patient-specific induced pluripotent stem-cell-derived models of leopard syndrome. Nature 2010, 465, 808-812. [CrossRef] [PubMed]

82. Shoji, E.; Sakurai, H.; Nishino, T.; Nakahata, T.; Heike, T.; Awaya, T.; Fujii, N.; Manabe, Y.; Matsuo, M.; Sehara-Fujisawa, A. Early pathogenesis of duchenne muscular dystrophy modelled in patient-derived human induced pluripotent stem cells. Sci. Rep. 2015, 5, 12831. [CrossRef] [PubMed]

83. Moretti, A.; Bellin, M.; Welling, A.; Jung, C.B.; Lam, J.T.; Bott-Flugel, L.; Dorn, T.; Goedel, A.; Hohnke, C.; Hofmann, F.; et al. Patient-specific induced pluripotent stem-cell models for long-qt syndrome. N. Engl. J. Med. 2010, 363, 1397-1409. [CrossRef] [PubMed]

84. Huang, H.P.; Chen, P.H.; Hwu, W.L.; Chuang, C.Y.; Chien, Y.H.; Stone, L.; Chien, C.L.; Li, L.T.; Chiang, S.C.; Chen, H.F.; et al. Human pompe disease-induced pluripotent stem cells for pathogenesis modeling, drug testing and disease marker identification. Hum. Mol. Genet. 2011, 20, 4851-4864. [CrossRef] [PubMed]

85. Kim, C.; Wong, J.; Wen, J.; Wang, S.; Wang, C.; Spiering, S.; Kan, N.G.; Forcales, S.; Puri, P.L.; Leone, T.C.; et al. Studying arrhythmogenic right ventricular dysplasia with patient-specific iPSCs. Nature 2013, 494, 105-110. [CrossRef] [PubMed]

86. Caspi, O.; Huber, I.; Gepstein, A.; Arbel, G.; Maizels, L.; Boulos, M.; Gepstein, L. Modeling of arrhythmogenic right ventricular cardiomyopathy with human induced pluripotent stem cells. Circ. Cardiovasc. Genet. 2013, 6, 557-568. [CrossRef] [PubMed]

87. Siu, C.W.; Lee, Y.K.; Ho, J.C.; Lai, W.H.; Chan, Y.C.; Ng, K.M.; Wong, L.Y.; Au, K.W.; Lau, Y.M.; Zhang, J.; et al. Modeling of lamin A/C mutation premature cardiac aging using patient-specific induced pluripotent stem cells. Aging 2012, 4, 803-822. [PubMed]

88. Dudek, J.; Cheng, I.F.; Balleininger, M.; Vaz, F.M.; Streckfuss-Bomeke, K.; Hubscher, D.; Vukotic, M.; Wanders, R.J.; Rehling, P.; Guan, K. Cardiolipin deficiency affects respiratory chain function and organization in an induced pluripotent stem cell model of barth syndrome. Stem Cell Res. 2013, 11, 806-819. [CrossRef] [PubMed]

89. Liu, J.; Verma, P.J.; Evans-Galea, M.V.; Delatycki, M.B.; Michalska, A.; Leung, J.; Crombie, D.; Sarsero, J.P.; Williamson, R.; Dottori, M.; et al. Generation of induced pluripotent stem cell lines from friedreich ataxia patients. Stem Cell Rev. 2011, 7, 703-713. [CrossRef] [PubMed]

90. Rashid, S.T.; Corbineau, S.; Hannan, N.; Marciniak, S.J.; Miranda, E.; Alexander, G.; Huang-Doran, I.; Griffin, J.; Ahrlund-Richter, L.; Skepper, J.; et al. Modeling inherited metabolic disorders of the liver using human induced pluripotent stem cells. J. Clin. Investig. 2010, 120, 3127-3136. [CrossRef] [PubMed]

91. Satoh, D.; Maeda, T.; Ito, T.; Nakajima, Y.; Ohte, M.; Ukai, A.; Nakamura, K.; Enosawa, S.; Toyota, M.; Miyagawa, Y.; et al. Establishment and directed differentiation of induced pluripotent stem cells from glycogen storage disease type ib patient. Genes Cells 2013, 18, 1053-1069. [CrossRef] [PubMed]

92. Maehr, R.; Chen, S.; Snitow, M.; Ludwig, T.; Yagasaki, L.; Goland, R.; Leibel, R.L.; Melton, D.A. Generation of pluripotent stem cells from patients with type 1 diabetes. Proc. Natl. Acad. Sci. USA 2009, 106, 15768-15773. [CrossRef] [PubMed]

93. Panicker, L.M.; Miller, D.; Park, T.S.; Patel, B.; Azevedo, J.L.; Awad, O.; Masood, M.A.; Veenstra, T.D.; Goldin, E.; Stubblefield, B.K.; et al. Induced pluripotent stem cell model recapitulates pathologic hallmarks of gaucher disease. Proc. Natl. Acad. Sci. USA 2012, 109, 18054-18059. [CrossRef] [PubMed]

94. Hamalainen, R.H.; Manninen, T.; Koivumaki, H.; Kislin, M.; Otonkoski, T.; Suomalainen, A. Tissue- and cell-type-specific manifestations of heteroplasmic mtDNA 3243a>g mutation in human induced pluripotent stem cell-derived disease model. Proc. Natl. Acad. Sci. USA 2013, 110, E3622-E3630. [CrossRef] [PubMed] 
95. Yasuno, T.; Osafune, K.; Sakurai, H.; Asaka, I.; Tanaka, A.; Yamaguchi, S.; Yamada, K.; Hitomi, H.; Arai, S.; Kurose, Y.; et al. Functional analysis of iPSC-derived myocytes from a patient with carnitine palmitoyltransferase ii deficiency. Biochem. Biophys. Res. Commun. 2014, 448, 175-181. [CrossRef] [PubMed]

96. Tucker, B.A.; Mullins, R.F.; Streb, L.M.; Anfinson, K.; Eyestone, M.E.; Kaalberg, E.; Riker, M.J.; Drack, A.V.; Braun, T.A.; Stone, E.M. Patient-specific iPSC-derived photoreceptor precursor cells as a means to investigate retinitis pigmentosa. Elife 2013, 2, e00824. [CrossRef] [PubMed]

97. Schwarz, N.; Carr, A.J.; Lane, A.; Moeller, F.; Chen, L.L.; Aguila, M.; Nommiste, B.; Muthiah, M.N.; Kanuga, N.; Wolfrum, U.; et al. Translational read-through of the RP2 Arg120stop mutation in patient iPSC-derived retinal pigment epithelium cells. Hum. Mol. Genet. 2015, 24, 972-986. [CrossRef] [PubMed]

98. Yoshida, T.; Ozawa, Y.; Suzuki, K.; Yuki, K.; Ohyama, M.; Akamatsu, W.; Matsuzaki, Y.; Shimmura, S.; Mitani, K.; Tsubota, K.; et al. The use of induced pluripotent stem cells to reveal pathogenic gene mutations and explore treatments for retinitis pigmentosa. Mol. Brain 2014, 7, 45. [CrossRef] [PubMed]

99. Jin, Z.B.; Okamoto, S.; Osakada, F.; Homma, K.; Assawachananont, J.; Hirami, Y.; Iwata, T.; Takahashi, M. Modeling retinal degeneration using patient-specific induced pluripotent stem cells. PLOS ONE 2011, 6, e17084. [CrossRef] [PubMed]

100. Lustremant, C.; Habeler, W.; Plancheron, A.; Goureau, O.; Grenot, L.; de la Grange, P.; Audo, I.; Nandrot, E.F.; Monville, C. Human induced pluripotent stem cells as a tool to model a form of leber congenital amaurosis. Cell. Reprogram. 2013, 15, 233-246. [PubMed]

101. Meyer, J.S.; Howden, S.E.; Wallace, K.A.; Verhoeven, A.D.; Wright, L.S.; Capowski, E.E.; Pinilla, I.; Martin, J.M.; Tian, S.; Stewart, R.; et al. Optic vesicle-like structures derived from human pluripotent stem cells facilitate a customized approach to retinal disease treatment. Stem Cells 2011, 29, 1206-1218. [CrossRef] [PubMed]

102. Singh, R.; Shen, W.; Kuai, D.; Martin, J.M.; Guo, X.; Smith, M.A.; Perez, E.T.; Phillips, M.J.; Simonett, J.M.; Wallace, K.A.; et al. IPS cell modeling of best disease: Insights into the pathophysiology of an inherited macular degeneration. Hum. Mol. Genet. 2013, 22, 593-607. [CrossRef] [PubMed]

103. Chang, Y.C.; Chang, W.C.; Hung, K.H.; Yang, D.M.; Cheng, Y.H.; Liao, Y.W.; Woung, L.C.; Tsai, C.Y.; Hsu, C.C.; Lin, T.C.; et al. The generation of induced pluripotent stem cells for macular degeneration as a drug screening platform: Identification of curcumin as a protective agent for retinal pigment epithelial cells against oxidative stress. Front. Aging Neurosci. 2014, 6, 191. [CrossRef] [PubMed]

104. Tulpule, A.; Kelley, J.M.; Lensch, M.W.; McPherson, J.; Park, I.H.; Hartung, O.; Nakamura, T.; Schlaeger, T.M.; Shimamura, A.; Daley, G.Q. Pluripotent stem cell models of shwachman-diamond syndrome reveal a common mechanism for pancreatic and hematopoietic dysfunction. Cell Stem Cell 2013, 12, 727-736. [CrossRef] [PubMed]

105. Batista, L.F.; Pech, M.F.; Zhong, F.L.; Nguyen, H.N.; Xie, K.T.; Zaug, A.J.; Crary, S.M.; Choi, J.; Sebastiano, V.; Cherry, A.; et al. Telomere shortening and loss of self-renewal in dyskeratosis congenita induced pluripotent stem cells. Nature 2011, 474, 399-402. [CrossRef] [PubMed]

106. Sakurai, M.; Kunimoto, H.; Watanabe, N.; Fukuchi, Y.; Yuasa, S.; Yamazaki, S.; Nishimura, T.; Sadahira, K.; Fukuda, K.; Okano, H.; et al. Impaired hematopoietic differentiation of RUNX1-mutated induced pluripotent stem cells derived from FPD/AML patients. Leukemia 2014, 28, 2344-2354. [CrossRef] [PubMed]

107. Zou, J.; Mali, P.; Huang, X.; Dowey, S.N.; Cheng, L. Site-specific gene correction of a point mutation in human ips cells derived from an adult patient with sickle cell disease. Blood 2011, 118, 4599-4608. [CrossRef] [PubMed]

108. Mali, P.; Chou, B.K.; Yen, J.; Ye, Z.; Zou, J.; Dowey, S.; Brodsky, R.A.; Ohm, J.E.; Yu, W.; Baylin, S.B.; et al. Butyrate greatly enhances derivation of human induced pluripotent stem cells by promoting epigenetic remodeling and the expression of pluripotency-associated genes. Stem Cells 2010, 28, 713-720. [CrossRef] [PubMed]

109. Ye, L.; Chang, J.C.; Lin, C.; Sun, X.; Yu, J.; Kan, Y.W. Induced pluripotent stem cells offer new approach to therapy in thalassemia and sickle cell anemia and option in prenatal diagnosis in genetic diseases. Proc. Natl. Acad. Sci. USA 2009, 106, 9826-9830. [CrossRef] [PubMed]

110. Matsumoto, Y.; Hayashi, Y.; Schlieve, C.R.; Ikeya, M.; Kim, H.; Nguyen, T.D.; Sami, S.; Baba, S.; Barruet, E.; $\mathrm{Nasu}, \mathrm{A} . ;$ et al. Induced pluripotent stem cells from patients with human fibrodysplasia ossificans progressiva show increased mineralization and cartilage formation. Orphanet J. Rare Dis. 2013, 8, 190. [CrossRef] [PubMed] 
111. Kim, D.; Choi, J.; Han, K.M.; Lee, B.H.; Choi, J.H.; Yoo, H.W.; Han, Y.M. Impaired osteogenesis in menkes disease-derived induced pluripotent stem cells. Stem Cell Res. Ther. 2015, 6, 160. [CrossRef] [PubMed]

112. Saitta, B.; Passarini, J.; Sareen, D.; Ornelas, L.; Sahabian, A.; Argade, S.; Krakow, D.; Cohn, D.H.; Svendsen, C.N.; Rimoin, D.L. Patient-derived skeletal dysplasia induced pluripotent stem cells display abnormal chondrogenic marker expression and regulation by BMP2 and TGFBETA1. Stem Cells Dev. 2014, 23, 1464-1478. [CrossRef] [PubMed]

113. Quarto, N.; Leonard, B.; Li, S.; Marchand, M.; Anderson, E.; Behr, B.; Francke, U.; Reijo-Pera, R.; Chiao, E.; Longaker, M.T. Skeletogenic phenotype of human marfan embryonic stem cells faithfully phenocopied by patient-specific induced-pluripotent stem cells. Proc. Natl. Acad. Sci. USA 2012, 109, 215-220. [CrossRef] [PubMed]

114. Chen, I.P.; Fukuda, K.; Fusaki, N.; Iida, A.; Hasegawa, M.; Lichtler, A.; Reichenberger, E.J. Induced pluripotent stem cell reprogramming by integration-free sendai virus vectors from peripheral blood of patients with craniometaphyseal dysplasia. Cell. Reprogram. 2013, 15, 503-513. [CrossRef] [PubMed]

115. Kim, J.; Hoffman, J.P.; Alpaugh, R.K.; Rhim, A.D.; Reichert, M.; Stanger, B.Z.; Furth, E.E.; Sepulveda, A.R.; Yuan, C.X.; Won, K.J.; et al. An iPSC line from human pancreatic ductal adenocarcinoma undergoes early to invasive stages of pancreatic cancer progression. Cell. Rep. 2013, 3, 2088-2099. [CrossRef] [PubMed]

116. Carette, J.E.; Pruszak, J.; Varadarajan, M.; Blomen, V.A.; Gokhale, S.; Camargo, F.D.; Wernig, M.; Jaenisch, R.; Brummelkamp, T.R. Generation of iPSCs from cultured human malignant cells. Blood 2010, 115, 4039-4042. [CrossRef] [PubMed]

117. Gandre-Babbe, S.; Paluru, P.; Aribeana, C.; Chou, S.T.; Bresolin, S.; Lu, L.; Sullivan, S.K.; Tasian, S.K.; Weng, J.; Favre, H.; et al. Patient-derived induced pluripotent stem cells recapitulate hematopoietic abnormalities of juvenile myelomonocytic leukemia. Blood 2013, 121, 4925-4929. [CrossRef] [PubMed]

118. Lee, D.F.; Su, J.; Kim, H.S.; Chang, B.; Papatsenko, D.; Zhao, R.; Yuan, Y.; Gingold, J.; Xia, W.; Darr, H.; et al . Modeling familial cancer with induced pluripotent stem cells. Cell 2015, 161, 240-254. [CrossRef] [PubMed]

119. Zhang, J.; Lian, Q.; Zhu, G.; Zhou, F.; Sui, L.; Tan, C.; Mutalif, R.A.; Navasankari, R.; Zhang, Y.; Tse, H.F.; et al. A human iPSC model of hutchinson gilford progeria reveals vascular smooth muscle and mesenchymal stem cell defects. Cell Stem Cell 2011, 8, 31-45. [CrossRef] [PubMed]

120. Leng, L.; Tan, Y.; Gong, F.; Hu, L.; Ouyang, Q.; Zhao, Y.; Lu, G.; Lin, G. Differentiation of primordial germ cells from induced pluripotent stem cells of primary ovarian insufficiency. Hum. Reprod. 2015, 30, 737-748. [CrossRef] [PubMed]

121. Mica, Y.; Lee, G.; Chambers, S.M.; Tomishima, M.J.; Studer, L. Modeling neural crest induction, melanocyte specification, and disease-related pigmentation defects in hescs and patient-specific iPSCs. Cell Rep. 2013, 3, 1140-1152. [CrossRef] [PubMed]

122. Singleton, A.B.; Farrer, M.; Johnson, J.; Singleton, A.; Hague, S.; Kachergus, J.; Hulihan, M.; Peuralinna, T.; Dutra, A.; Nussbaum, R.; et al. $\alpha$-Synuclein locus triplication causes Parkinson's disease. Science 2003, 302, 841. [CrossRef] [PubMed]

123. Chartier-Harlin, M.C.; Kachergus, J.; Roumier, C.; Mouroux, V.; Douay, X.; Lincoln, S.; Levecque, C.; Larvor, L.; Andrieux, J.; Hulihan, M.; et al. $\alpha$-synuclein locus duplication as a cause of familial Parkinson's disease. Lancet 2004, 364, 1167-1169. [CrossRef]

124. Quarto, N.; Li, S.; Renda, A.; Longaker, M.T. Exogenous activation of BMP-2 signaling overcomes TGF $\beta$-mediated inhibition of osteogenesis in Marfan embryonic stem cells and Marfan patient-specific induced pluripotent stem cells. Stem Cells 2012, 30, 2709-2719. [CrossRef] [PubMed]

125. Drachtman, R.A.; Alter, B.P. Dyskeratosis congenita. Dermatol. Clin. 1995, 13, 33-39. [PubMed]

126. Agarwal, S.; Loh, Y.H.; McLoughlin, E.M.; Huang, J.; Park, I.H.; Miller, J.D.; Huo, H.; Okuka, M.; Dos Reis, R.M.; Loewer, S.; et al. Telomere elongation in induced pluripotent stem cells from dyskeratosis congenita patients. Nature 2010, 464, 292-296. [CrossRef] [PubMed]

127. Hu, B.Y.; Weick, J.P.; Yu, J.; Ma, L.X.; Zhang, X.Q.; Thomson, J.A.; Zhang, S.C. Neural differentiation of human induced pluripotent stem cells follows developmental principles but with variable potency. Proc. Natl. Acad. Sci. USA 2010, 107, 4335-4340. [CrossRef] [PubMed]

128. Sanchez-Freire, V.; Lee, A.S.; Hu, S.; Abilez, O.J.; Liang, P.; Lan, F.; Huber, B.C.; Ong, S.G.; Hong, W.X.; Huang, M.; et al. Effect of human donor cell source on differentiation and function of cardiac induced pluripotent stem cells. J. Am. Coll. Cardiol. 2014, 64, 436-448. [CrossRef] [PubMed] 
129. Chin, M.H.; Mason, M.J.; Xie, W.; Volinia, S.; Singer, M.; Peterson, C.; Ambartsumyan, G.; Aimiuwu, O.; Richter, L.; Zhang, J.; et al. Induced pluripotent stem cells and embryonic stem cells are distinguished by gene expression signatures. Cell Stem Cell 2009, 5, 111-123. [CrossRef] [PubMed]

130. Deng, J.; Shoemaker, R.; Xie, B.; Gore, A.; LeProust, E.M.; Antosiewicz-Bourget, J.; Egli, D.; Maherali, N.; Park, I.H.; Yu, J.; et al. Targeted bisulfite sequencing reveals changes in DNA methylation associated with nuclear reprogramming. Nat. Biotechnol. 2009, 27, 353-360. [CrossRef] [PubMed]

131. Laurent, L.C.; Ulitsky, I.; Slavin, I.; Tran, H.; Schork, A.; Morey, R.; Lynch, C.; Harness, J.V.; Lee, S.; Barrero, M.J.; et al. Dynamic changes in the copy number of pluripotency and cell proliferation genes in human ESCs and iPSCs during reprogramming and time in culture. Cell Stem Cell 2011, 8, 106-118. [CrossRef] [PubMed]

132. Mayshar, Y.; Ben-David, U.; Lavon, N.; Biancotti, J.C.; Yakir, B.; Clark, A.T.; Plath, K.; Lowry, W.E.; Benvenisty, N. Identification and classification of chromosomal aberrations in human induced pluripotent stem cells. Cell Stem Cell 2010, 7, 521-531. [CrossRef] [PubMed]

133. Lee, E.; Iskow, R.; Yang, L.; Gokcumen, O.; Haseley, P.; Luquette, L.J., 3rd; Lohr, J.G.; Harris, C.C.; Ding, L.; Wilson, R.K.; et al. Landscape of somatic retrotransposition in human cancers. Science 2012, 337, 967-971. [CrossRef] [PubMed]

134. Hamdorf, M.; Idica, A.; Zisoulis, D.G.; Gamelin, L.; Martin, C.; Sanders, K.J.; Pedersen, I.M. miR-128 represses L1 retrotransposition by binding directly to L1 RNA. Nat. Struct. Mol. Biol. 2015, 22, 824-831. [CrossRef] [PubMed]

135. Zhao, T.; Zhang, Z.N.; Rong, Z.; Xu, Y. Immunogenicity of induced pluripotent stem cells. Nature 2011, 474, 212-215. [CrossRef] [PubMed]

136. Doi, A.; Park, I.H.; Wen, B.; Murakami, P.; Aryee, M.J.; Irizarry, R.; Herb, B.; Ladd-Acosta, C.; Rho, J.; Loewer, S.; et al. Differential methylation of tissue- and cancer-specific CpG island shores distinguishes human induced pluripotent stem cells, embryonic stem cells and fibroblasts. Nat. Genet. 2009, 41, 1350-1353. [CrossRef] [PubMed]

137. Kim, K.; Doi, A.; Wen, B.; Ng, K.; Zhao, R.; Cahan, P.; Kim, J.; Aryee, M.J.; Ji, H.; Ehrlich, L.I.; et al. Epigenetic memory in induced pluripotent stem cells. Nature 2010, 467, 285-290. [CrossRef] [PubMed]

138. Polo, J.M.; Liu, S.; Figueroa, M.E.; Kulalert, W.; Eminli, S.; Tan, K.Y.; Apostolou, E.; Stadtfeld, M.; Li, Y.; Shioda, T.; et al. Cell type of origin influences the molecular and functional properties of mouse induced pluripotent stem cells. Nat. Biotechnol. 2010, 28, 848-855. [CrossRef] [PubMed]

139. Tang, C.; Drukker, M. Potential barriers to therapeutics utilizing pluripotent cell derivatives: Intrinsic immunogenicity of in vitro maintained and matured populations. Semin. Immunopathol. 2011, 33, 563-572. [CrossRef] [PubMed]

140. Martin, M.J.; Muotri, A.; Gage, F.; Varki, A. Human embryonic stem cells express an immunogenic nonhuman sialic acid. Nat. Med. 2005, 11, 228-232. [CrossRef] [PubMed]

141. Lu, Q.; Yu, M.; Shen, C.; Chen, X.; Feng, T.; Yao, Y.; Li, J.; Li, H.; Tu, W. Negligible immunogenicity of induced pluripotent stem cells derived from human skin fibroblasts. PLoS ONE 2014, 9, e114949.

142. Guha, P.; Morgan, J.W.; Mostoslavsky, G.; Rodrigues, N.P.; Boyd, A.S. Lack of immune response to differentiated cells derived from syngeneic induced pluripotent stem cells. Cell Stem Cell 2013, 12, 407-412. [CrossRef] [PubMed]

143. Morizane, A.; Doi, D.; Kikuchi, T.; Okita, K.; Hotta, A.; Kawasaki, T.; Hayashi, T.; Onoe, H.; Shiina, T.; Yamanaka, S.; et al. Direct comparison of autologous and allogeneic transplantation of iPSC-derived neural cells in the brain of a non-human primate. Stem Cell Rep. 2013, 1, 283-292. [CrossRef] [PubMed]

144. Todorova, D.; Kim, J.; Hamzeinejad, S.; He, J.; Xu, Y. Brief Report: Immune microenvironment determines the immunogenicity of induced pluripotent stem cell derivatives. Stem Cells 2015. [CrossRef] [PubMed]

(C) 2016 by the authors; licensee MDPI, Basel, Switzerland. This article is an open access article distributed under the terms and conditions of the Creative Commons by Attribution (CC-BY) license (http://creativecommons.org/licenses/by/4.0/). 